\title{
Real Exchange Rates and Manufacturing Industry in China
}

\author{
Ping HUA

\begin{abstract}
Clermont Auvergne University, French National Center for Scientific Research, French National Research Institute for Sustainable
\end{abstract} \\ Development, Study and Research Center for International Development, France
}

Received September 22, 2019; Revised March 12, 2020; Accepted March 19, 2020

Copyright $\bigcirc 2020$ by authors, all rights reserved. Authors agree that this article remains permanently open access under the terms of the Creative Commons Attribution License 4.0 International License

\begin{abstract}
The Chinese real manufacturing value added increased at a higher growth rate (17\% per year on average) during the strong depreciation period of the renminbi from 1984 to 1993 than that $(10 \%)$ during the period of the strong appreciation from 1994 to 2016. On contrary, its productivity growth accelerated at an annual average rate of $9.7 \%$ during the real appreciation period relative to $3.6 \%$ during the real depreciation period. This paper originally argues that real appreciation of exchange rate may improve manufacturing productivity (rarely studied), mitigating its traditional negative effects; its total effect is thus uncertain; only an empirical investigation can reveal it. We propose a manufacturing value added function augmented of real exchange rate able to estimate these two kinds of effects. To this objective, we calculate three renminbi real exchange rates for the Chinese manufacturing at macro, product and sector levels. The obtained results confirm that the renminbi real appreciation exerted traditional negative effects on the size of tradable sector and employment, but positive effects on capital intensity, efficiency improvement of workers and staffs and competitiveness via Schumpeterian "creative destruction," innovation and high technology industries. The positive effects on manufacturing value added are however still too small to offset the negative ones. These results suggest that China should gradually revalue the renminbi in function of manufacturing productivity improvement to avoid the serious deceleration of manufacturing industry when its negative impacts on the size of tradable sector, resource allocation to non-tradable sector and employment are superior to positive effects of productivity improvement.
\end{abstract}

\section{Keywords Manufacturing Value Added, Real Exchange Rates, China}

JEL: F31, F41, F62

\section{Introduction}

The success of China's exports outward-oriented manufacturing is incontestable. The real manufacturing value added increased at an annual average growth rate of $12 \%$ over the period from 1983 to 2016 . It has allowed China to become the biggest world manufacturer by real manufacturing value added in 2009. However, China's manufacturing industry arrived at turning point in 1994. The annual growth rate of real manufacturing value added continually decreased from $28 \%$ in 1994 to $5.9 \%$ in 2016 , which is the lowest level since $1983^{1}$. This turning point corresponds to the radical change of China's exchange rate policies with objective since 1994 to stabilize and to revalue the renminbi vis-à-vis the dollar, while it was systematically devalued during the period $1984-1993 .^{2}$

This observation supports the traditional argument that real depreciation favours exports-led growth model, while real appreciation decreases it $^{3}$. There is a significant literature regarding the negative impact of real exchange rate appreciation on growth, particularly for developing countries, ${ }^{4}$ which is mainly seen in manufacturing industry (Razmi et al., 2012) and its related employment (Hua, 2007; Chen \& Dao, 2011). Two arguments justify the necessary to keep real depreciation particularly at the beginning of industrlisation when manufacturing is often more productive than agriculture or services with learning spillovers. However, its development is more handicapped than other sectors by bad institutions increasing production costs and disadvantages of the greater complexity of

\footnotetext{
1 Except for 1989 and 1990 years of the social movement when the industrial activities almost stagnated.

2 The renminbi was devaluated of $70 \%$ against the dollar in real terms during the period from 1984 to 1994 (Fig. 2).

3 Fig 3a showed a negative relationship between real appreciation of the renminbi and growth rate of manufacturing value added.

4 See Dollar, 1992; Benaroya \& Janci, 1999; Hausmann, Pritchett \& Rodrik, 2005; Eichengreen, 2008; Berg \& Miao, 2010; MacDonald \& Vieira, 2010; Hua, 2012; Rodrik, 2016 among others.
} 
production processes. Since manufacturing production is an internationally tradable good, undervaluing the currency may compensate for this handicap and this disadvantage (Rodrik, 2008). China is a recent success example of labor-intensive export-led industrialization thanks to its active real devaluations (Guzman et al., 2018).

Certainly manufacturing development depends relative price competition (via devaluations). It also depends manufacturing productivity improvement during industrialization process to offset the rise of labor cost. Chinese manufacturing labor costs have been rising steadily and very quickly. The minimum wage in Shenzhen is about US\$ 4032 per year, which are more than double than that in several Southeast Asian countries (Leng, 2018). China has lost its comparative advantage in low cost labor-intensive industry, and has no choice than upgrading and improving productivity.

Real appreciation may help productivity improvement through its potential positive effects via reduced cost of imports, efficiency and innovation. First, the reduced cost of imported machines and equipment favours capital-intensive manufacturing industry and push labour-intensive industry to be more capital intensity. Ce phenomena is particularly important in Chinese textile and clothing societies, which have no choice either to close down or to upgrade product lines via robotic and automated technology (Sharif and Huang, 2019). In 2018, Chinese factories had 140 robots on average for 10,000 employees, twice as many as in 2016. Chinese customers imported about a third of the world's robot production. Second, real appreciation exerts positive "X-efficiency", pushes management effort near to its optimum (Krugman, 1989) and exacerbates competition via Schumpeterian "creative destruction" benefiting to the most performing manufacturing enterprises ${ }^{5}$. It pushed up Chinese manufacturing labor productivity improvement as a kind of virtuous circle: the renminbi real appreciation boosts the growth of manufacturing labour productivity while, according to the Balassa-Samuelson effect, productivity growth tends to push up the real appreciation (Guillaumont Jeanneney and Hua, 2011). Finally, real appreciation puts societies under strong pressure, which have to increase their spending on $R \& D$ and to innovate to stay competitively (Harris, 2002). Boeing et al. (2015) showed the R \& D explosion increased productivity. Jefferson et al. (2006) and Huang et al. (2019) find positive effects of $\mathrm{R} \& \mathrm{D}$ to new product innovation and productivity in China. Dai et al. (2019) showed that firm innovation contributes productivity growth. The Chinese manufacturing labour

5 Schumpeter (1942) first used the term of "creative destruction" which describes the process of industrial mutation that incessantly revolutionizes the economic structure by destroying the old one and creating a new one. The positive effects of the real appreciation are studied in Harris (2001) in the case of Canada, in Gebre-Ebziabher (2009). Redi (2009) and Sonobe. Akoten \& Otsuka. 2009) in the case of Ethiopian shoe industry and in Guillaumont-Jeanneney and Hua (2011), Brandt et al. (2012); Hua (2012), Zhou et al. (2017) in the case of China. productivity growth accelerated during the real appreciation period at an annual average rate of $9.7 \%$ relative to $3.6 \%$ during the real depreciation period. This supports our hypothesis that real appreciation improves productivity ${ }^{6}$.

This study originally proposes a manufacturing model, which allows identifying the above potential positive effects of real appreciation on manufacturing productivity besides its traditional impacts. To this objective, we define a function of manufacturing value added which includes real exchange rate, employment, capital intensity and factors influencing the size of tradable sector (such as exports, FDI and the development of the private manufacturing sector) which are themselves supposed to depend on the real exchange rate. As all control variables are added into the function, real exchange rate captures its effect on productivity. We calculate three real exchange rates for the Chinese manufacturing at macro, product and sector levels. The obtained results confirm a positive effect of real appreciation on manufacturing capital intensity and productivity improvement, which is still smaller than the negative effect on the size of tradable sector and employment in China.

The rest of the paper is organized as follows. The following section compares the evolution of China's manufacturing industry relative to that of real exchange rate. In third section, we argue how theoretically real appreciation may affect (positively or negatively) manufacturing value added, either directly or through its traditional factors, and thus to conclude that the sign of the total effect is theoretically ambiguous and only an empirical analysis can reveal it. In forth section, we estimate a function of manufacturing value added in the case of China. We draw some economic and political implications in conclusion.

\section{Evolution of the Chinese Manufacturing Compared to That of Real Exchange Rate}

\subsection{Chinese Manufacturing Value Added}

The Chinese manufacturing industry increased very quickly. The real manufacturing value added (in 2010 constant RMB) increased at an annual average growth rate of $12 \%$ from 521 billion in 1983 to 20168 billion in 2016. In 1978 , China ranked $14^{\text {th }}$ by real manufacturing value added which represented only $1.1 \%$ of the world total. Its fast growth rate allows China to displace Germany to become the third biggest one in 2002, and then the second one in 2006 by over taking Japan and the biggest one in

6 Fig $3 b$ shows a positive relationship between renminbi real appreciation and manufacturing productivity. 
2009 by displacing the United States. In 2016, its share in the world total represented $24 \%$ against $15 \%$ for the United-States. China created almost one quarter of manufacturing value added. India followed China's steps and became the fifth most important manufacturing country in 2016. This suggests that China has no choice than upgrading its manufacturing.

Chinese manufacturing industry is upgrading. Very recently (published in February 2018), World Input-Output database published sectorial value added according to ISIC 4 classification over the period from 2000 to 2014. Among the 18 manufacturing sectors, the share of the value added of computer, electronic and optical products in total MVA increased from $1 \%$ in 2000 to $9 \%$ in 2014. UNIDO (2010) classifies the 18 sectors at the 2-digit level of ISIC Rev 4 into medium-high and high technology ( $\mathrm{MH}$ and $\mathrm{H}$ ), medium technology $(\mathrm{MH})$ and low technology $(\mathrm{LH})$ in function of technological intensity defined as ratio of R\&D expenditure to gross value added. The real value added of $\mathrm{MH}$ and $\mathrm{H}$ in China (in 2010 yuans) increased the quickest, from 655 billion in 2000 to 7809 billion in 2014, i.e. at an annual average rate of $21 \%$. It followed by $\mathrm{MH}$ which passed from 968 billion to 4041 billion (at annual average growth rate of 12\%) and by LH from 1386 billion to 6445 billion (at an annual average growth rate of $13 \%$ ). Thus, since 2009 the medium-high and high technology manufacturing is the biggest sector (Fig. 1).

The analysis of trade data also shows that the share of labor-intensive manufacturing goods decreased in favor of that of capital or high technological products in China. The export shares of textiles and clothing and low technologies decreased from $31 \%$ and $45 \%$ in 1992 to $13 \%$ and $30 \%$ in 2016 while that of machine and transport equipment and high technologies increased from $15 \%$ and $8 \%$ to $47 \%$ and
$32 \%$ respectively.

\subsection{China's Exchange Rate Policies}

China's exchange rate regime is the fruit of a long evolution from two exchange rates to a unique rate. From 1981 to 1993 export societies have benefited from the administrated rate/swap market rate depreciated relative to official one and the foreign exchange retention system. The Chinese government devalued the two exchange rates against the dollar several times and increased the retention rate up to $80 \%$ in 1993 . The devaluations were not realized simultaneously to favour the real depreciation of exchange rate for export promotion. The nominal and real depreciations vis-à-vis the dollar were in fact large (respectively $53 \%$ and $37 \%$ for the official rate over the period from 1990 to 1993).

On $1^{\text {st }}$ January 1994 , China radically changed its policy. The double exchange rate system was suppressed; the swap rate became the unique official rate for all transactions; a managed floating was officially adopted. On 21 July 2005 , the Chinese authorities revalued the renminbi of $2.1 \%$ vis-à-vis the dollar, progressively revalued until $2014(25 \%$ in terms of dollars), and devalued it since 2015. China progressively switched from the dollar peg to a basket of four currencies in 2005 to 24 currencies in 2017. It allowed the RMB to float more freely from a band of $0.3 \%$ around precedent daily rate in 2005 to of $2 \%$ in March 2014. This exchange rate policy led the evolution of the real effective exchange rate marked by a period of depreciation of $51 \%$ from 1984 to 1993 and a period of appreciation of $50 \%$ from 1994 to 2016 (Fig. 2).

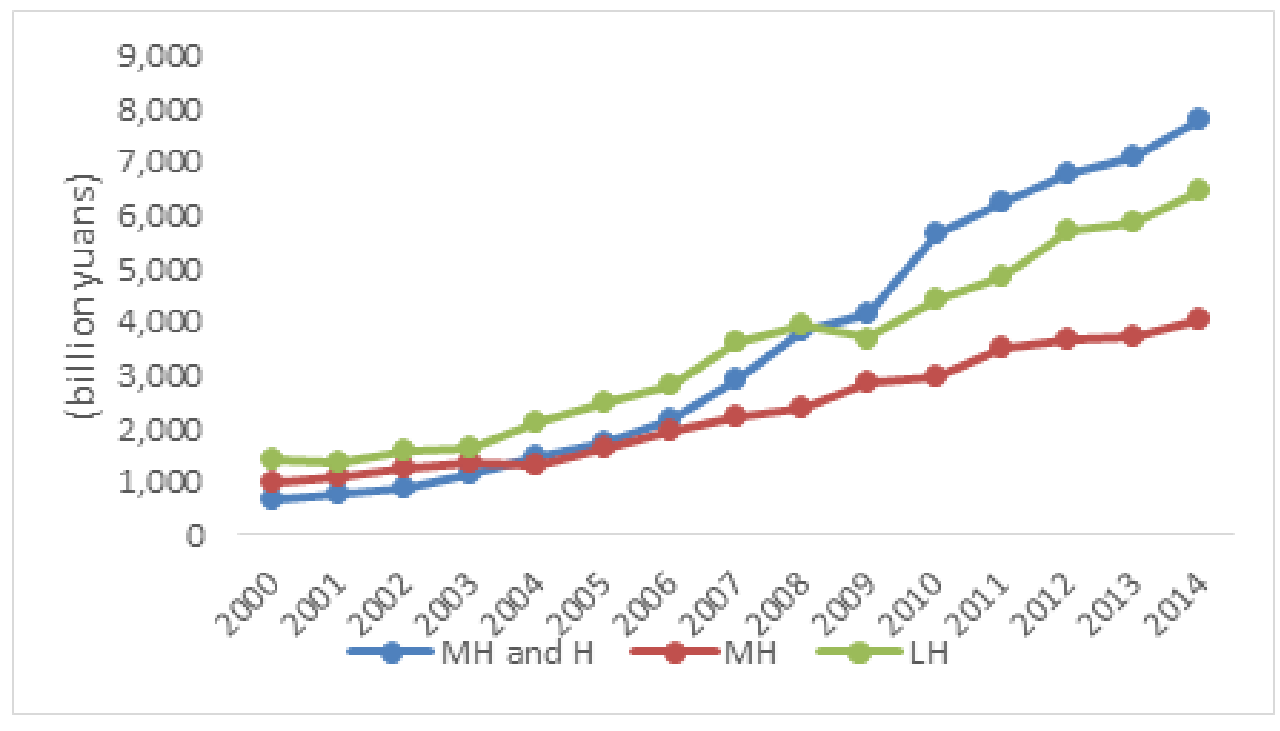

Source: World Input-Output database.

Figure 1. Evolution of the Chinese manufacturing value added by technological intensity from 2000 to 2014 


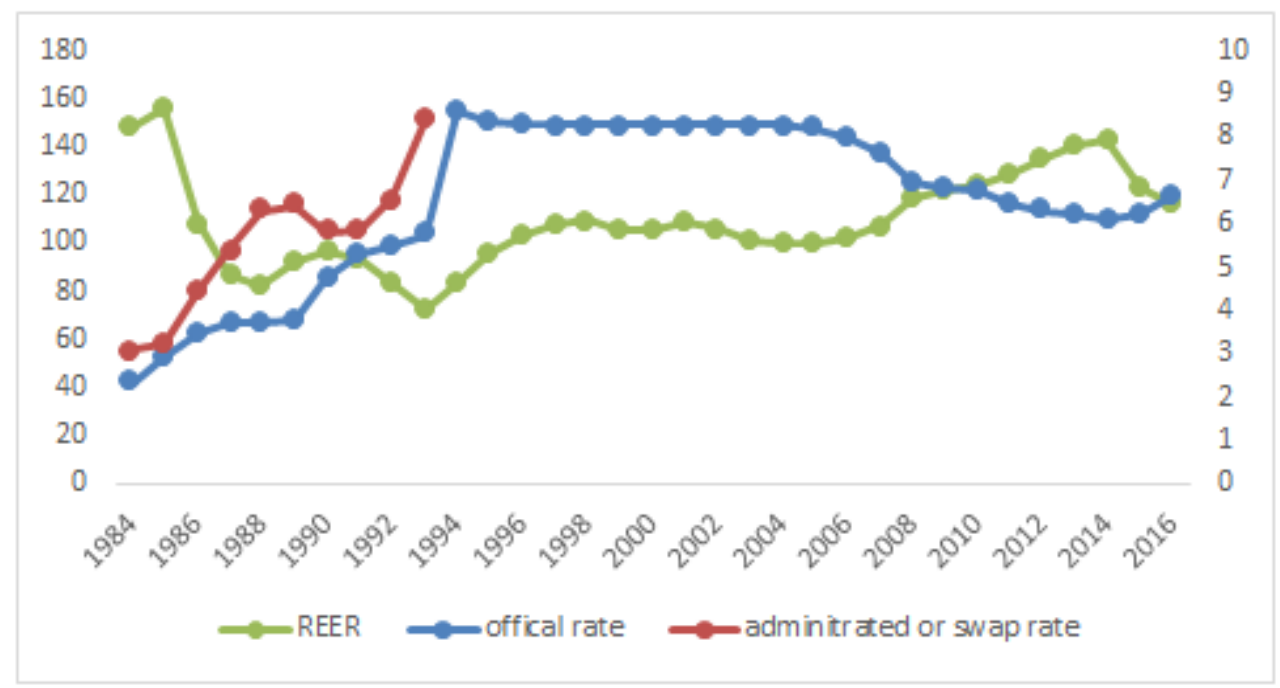

NB: A rise of official or administrated rates means a renminbi depreciation against dollar. A rise of real effective exchange rate means a real renminbi appreciation against its main exports partners.

Source: International Financial Statistics IMF, China Statistical Yearbooks.

Figure 2. Official and administrated/swaps rates and real effective exchange rate in China

\subsection{Statistical Relationship between Real Exchange Rates and Manufacturing Value Added}

Figure 3a shows a negative relationship between the real appreciation of the renminbi and the growth rate of real manufacturing value added. It suggests that the Chinese manufacturing industry accelerated during the periods of the real depreciation while decelerated during the period of appreciation in terms of volumes. On contrary, figure $3 \mathrm{~b}$ shows a positive relationship between the renminbi real appreciation and the Chinese manufacturing productivity, suggesting that real appreciation may favour manufacturing productivity improvement.
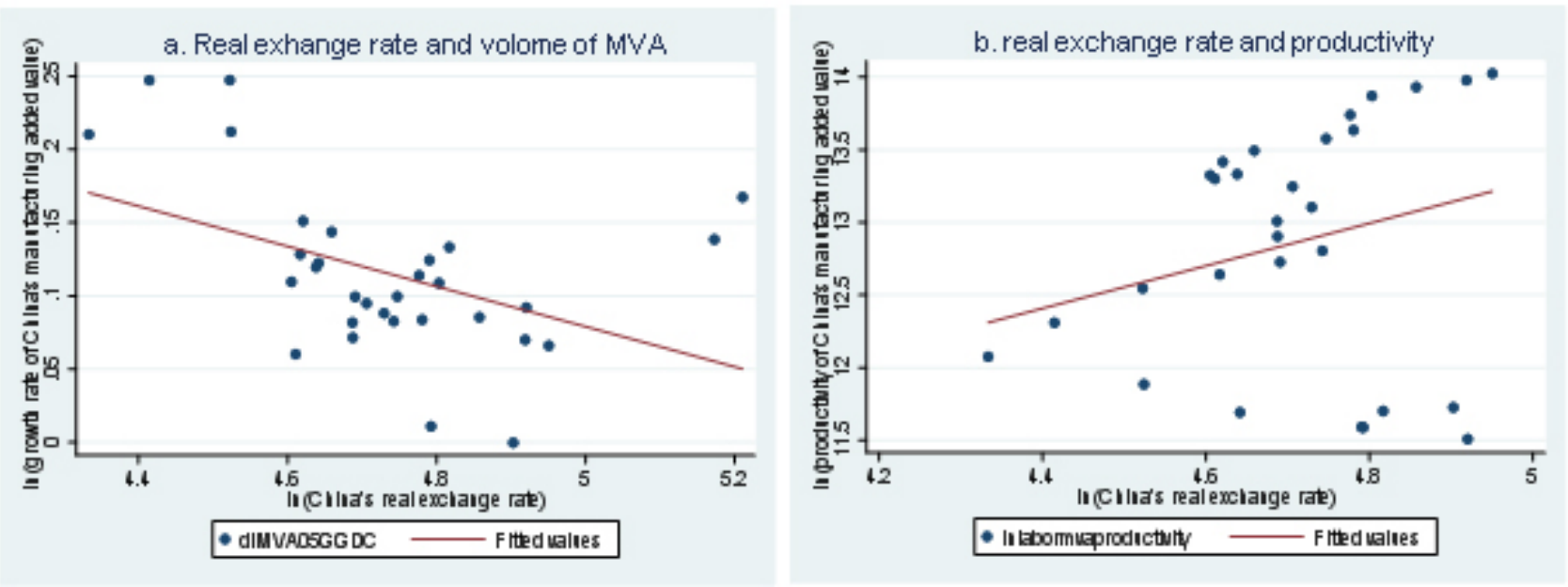

Source: International Financial Statistics IMF, GGDC, UNSD.

Figure 3. Statistical relationship between real exchange rate and growth rate or productivity of manufacturing value added in China over the period from 1984 to 2016 
However, this simple statistical relationship does not take the other determinants of manufacturing value added into account and does not allow to identify the transmission channels through which real exchange rate may act on. We thus propose in next section a model of manufacturing determinants.

\section{A Model of the Impacts of Real Exchange Rate on Manufacturing Value Added in China}

We propose a manufacturing function augmented of real exchange rates to analyze the different impacts of real exchange rates on manufacturing value added along with other explanatory variables, which are themselves influenced by real exchange rate.

\subsection{Manufacturing Value Added Function}

According to the methodology of growth accounting, manufacturing value added growth is divided into a component explained by input growth and a 'residual' which captures changes in productivity. Consider the following Cobb-Douglas manufacturing production functions:

$$
M V A=A K^{\alpha} L^{\beta}
$$

Where MVA represents real manufacturing value added, A is total factor productivity, $\mathrm{K}$ real capital stock and $\mathrm{L}$ employed population in manufacturing sector. As Chinese manufacturing industry has been capital intensive-driven development, we rewrite the above equation as following

$$
M V A=A(K / L)^{\alpha} L^{(\alpha+\beta)}
$$

The main factors, which improve productivity, are the size of the tradable sector. It is well known that China's open door policies have led a strong development of manufactured exports (X) (Fu \& Balasubramanyam 2005, Kraay 2006) associated with the strong inflow of foreign direct investments (FDI) and the promotion of the private sector (PRIV) (Jefferson \& Su 2006, Dougherty et al. 2007). Li et al. (2001) argued the positive effect of FDI on productivity. Chen et al. (2019) found that private firms are much more efficient than SOEs. The above function can be written as follows (with the expected signs):

$$
M V A=a_{0} X^{a 1} F D I^{a 2} P R I V^{a 3}(K / L)^{\alpha} L^{(\alpha+\beta)}
$$

\subsection{Manufacturing Value Added Function Augmented of Real Exchange Rate}

Real exchange rate can affect manufacturing value added via its indirect impacts on the size of tradable sector, employment and capital intensity as transmission channels and via its direct effect on efficiency, on competition via Schumpeterian "creative destruction" and on innovation and manufacturing upgrading.

\subsubsection{Negative Impact of Real Exchange Rate Appreciation}

Real exchange rate appreciation causes deterioration in the international competitiveness of domestic enterprises relative to their foreign competitors and leads to a reduction in exports of manufactured goods. This deterioration reduces the profits of the export sector of manufactured goods. It decreases industrial self-financing and the will to invest in the industrial sector, and more generally in the tradable goods sector. Resources are incited to go non-tradable sector. The renminbi real appreciation incites Chinese manufacturing enterprises, especially labor-intensive ones, to invest in the estate sector etc. instead of investing in manufacturing. The increase of housing price rises in return the living cost, damaging manufacturing competitiveness. ${ }^{7}$ If the tradable goods sector is the most efficient and innovative sector, real exchange rate appreciation may affect manufacturing industry negatively, in addition to its impact on exports-led firms.

The depreciated renminbi during 1983-1993 period was particularly good for manufacturing growth in China, because it allowed creation and promotion of the small and efficient tradable sectors, which suffered disproportionately from institutional and market failures relative to state-owned enterprises. Many private manufacturing enterprises were created during this period so well that the Chinese manufacturing was in overproduction since the beginning of 1990s. The real appreciated renminbi since then exerted an inverse effect. The strong real appreciation of $20 \%$ of the renminbi since 2010 strongly decreased the manufacturing benefits and discouraged the development of the manufacturing industry whose annual growth rate decreased from $13 \%$ in 2010 to $5.9 \%$ in 2016 , as well as exports of manufacturing goods whose growth rate decreased from $28 \%$ in 2010 to $8 \%$ in 2016.

The negative effect of real appreciation on the size of tradable sector is also seen in the decrease in foreign direct investments (FDI), which declined rapidly during the renminbi appreciation period from a peak of $73 \%$ in 2005 to $49 \%$ in 2010 , and has declined further to $26 \%$ in 2016 . Foreign firms bring technological improvements and their know-how to China. This positive action occurs through the creation of foreign companies or joint-ventures which are more productive than domestic firms, suppliers or customers of the foreign enterprises. Lovely et al. (2018) argue that FDI favor the upgrading from low tech to high tech manufacturing. Moreover, real appreciation exerts a negative impact on the size of the tradable sector by decreasing the relative importance of private enterprises,

7 Huawei left Shenzhen due to high housing prices (China Banking News, 4 July 2018). 
which are the most dynamic enterprises in the manufacturing sector. Finally, a real exchange rate appreciation has negative effects on employment not only in tradable sector but also in services as an intermediate input in export production ((Hua 2007; Chen \& Dao, 2011).

The above arguments concerning the negative effects of real exchange rate appreciation on the size of the tradable sector and employment can be therefore captured by the following equations (with the expected waited signs):

$$
\begin{gathered}
X=f(R E R), F D I=f(R E R), \\
P R I V=f(R E R), L=f(R E R)
\end{gathered}
$$

\subsubsection{Positive Impact of Real Appreciation of Exchange Rates}

A real appreciation reduces the relative cost of imported capital goods. It encourages more capitalist forms of production and technological innovations and so increases manufacturing growth. The real appreciation may have favored investment-led manufacturing industry in China since the 1990's. The above arguments can be resumed by the following equations with expected signs as follows (with the expected signs): $K / L=f(R E R)$

A real exchange rate appreciation increases the real remuneration of unqualified workers, which causes efficiency improvements known as "X-efficiency" by workers in a country where the wages of unskilled workers relative to living costs are still low. This is the case of Chinese migrants whose wages are sometimes lower than the living costs. A labor remuneration that is too low might make migrant workers unhealthy and reduce their capacity for work. Second, a real appreciation could push firms to improve their technical efficiency due to foreign competitors (Krugman, 1989). The managers choose a higher level of effort by eliminating excess labour or possibly by introducing labour-saving techniques in order to increase the profit in the short run, and to dissuades competitors from entering into the market and thus to avoid a fall in the price. Due to this strategic yield, there exists an additional benefit induced by the effort, which may push management effort near to its optimum. The intensification of foreign competition due to currency real appreciation improves productivity of manufactured firms as some of them are obliged to close their poorer performing factories, or even to close down completely; it is a kind of Schumpeterian "creative destruction" which benefits the enterprises which perform best. Under the pressure of the renminbi appreciation since 1994, Chinese firms are increasingly exposed to foreign competition, and a large number of firms were obliged to reform their management or to close down. It is reported that more than 4000 enterprises were closed in 2014 in Dongguan, a key manufacturing city in southern China's Guangdong province (Salvacion, 2015). The intensification of foreign competition due to appreciation is also favorable to innovation and creation of new products (Alfaro et al., 2018; Dai et al. 2019). The positive effect of the real exchange rate can be captured by adding real exchange rate into the equation as follows:

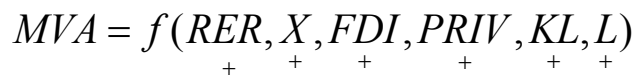

As all the control variables are added into the equation, the coefficient of the real exchange rate measures only the effects that are not captured by the variables of transmission channels and notably the direct effects on work effort. Its expected sign is positive. The overall effect of the real appreciation of exchange rate on manufacturing is therefore uncertain. Only an econometric estimation may reveal it.

\section{Econometric Model and Estimation}

We present an econometric model, its estimation strategy and results.

\subsection{Econometric Model to Be Estimated}

To estimate the different effects of real exchange rates on manufacturing value added, we proceed in two steps. First, we estimate the following equation in estimation form as follows:

$$
\begin{gathered}
\ln M V A_{t}=a_{0}+a_{1} \ln R E R+a_{2} \ln X_{t}+a_{3} \ln F D I_{t} . \\
+a_{4} \ln P R I V_{t}+a_{5} \ln K / L_{t}+a_{6} \ln L_{t}+\varepsilon_{t}
\end{gathered}
$$

The variables are expressed in logarithms so that the coefficients represent elasticities with positive expected signs. As all variables of transmission channels are introduced in the equation, $a_{1}$ captures the positive effect of real exchange rate on productivity improvement.

In the second step, we look for the effect of the real exchange rate, which is exerted indirectly via the other variables that we have assumed to explain the manufacturing: exports, foreign direct investments, private enterprises, capital intensity and employment. We estimate separately the impact of real exchange rate on the transmission channel variables as following.

$$
\begin{gathered}
\ln X_{t}=b_{0}+b_{1} \ln R E R_{t}+\varepsilon_{t 1} \\
\ln F D I_{t}=c_{0}+c_{1} \ln R E R_{t}+\varepsilon_{t 3} \\
\ln P R I V_{t}=d_{0}+d_{1} \ln R E R_{t}+\varepsilon_{t 4} \\
\ln K L_{t}=e_{0}+e_{1} \ln R E R_{t}+\varepsilon_{i 5} \\
\ln L_{t}=f_{0}+f_{1} \ln R E R_{t}+\epsilon_{i t 6}
\end{gathered}
$$


Table 1. Effects of real exchange rate appreciation on manufacturing

\begin{tabular}{|c|c|c|c|}
\hline Effects & Coefficients & Long-run & Short-run \\
\hline Productivity effects & a1 & 0.29 & 0.17 \\
\hline ordinary exports & $\mathrm{a} 2 \mathrm{~b} 1$ & -0.06 & -0.01 \\
\hline FDI & $\mathrm{a} 3 \mathrm{c} 1$ & -0.17 & -0.07 \\
\hline private sector & $\mathrm{a} 4 \mathrm{~d} 1$ & -0.23 & -0.02 \\
\hline Employment & a5e 1 & -0.31 & -0.08 \\
\hline capital intensity & a6f1 & 0.13 & NS \\
\hline total effects & $\left(a_{1}+a_{2} b_{1}+a_{3} c_{1}+a_{4} d_{1}+a_{5} e_{1}+a_{6} f_{1}\right)$ & -0.35 & -0.01 \\
\hline
\end{tabular}

The expected elasticity signs of all equations are negative except equation 5 . The estimation results allow knowing if these channeling variables are effectively the transmission channels, through which real exchange rate affects manufacturing. The effects are calculated by multiplying the manufacturing value added elasticity relative to the real exchange rate $\left(a_{1}\right.$ in equation 1$)$ respectively by the elasticities of the determinants of manufacturing value added relative to the real exchange rate $\left(b_{1}, c_{1}, d_{1}, e_{1}, f_{1}\right.$, in equations 2 to 6$)$. In this way we can evaluate precisely the contribution of each intermediary variable to the effect exerted by real exchange rate on manufacturing value added. Total effect of real exchange rate is the sum of all effects such as $\left(a_{1}+a_{2} b_{1}+a_{3} c_{1}+a_{4} d_{1}+a_{5} e_{1}+a_{6} f_{1}\right)$ in which $\mathrm{a}_{1}$ and $\mathrm{a}_{5} \mathrm{e}_{1}$ are positive, while the other are negative (Table 1).

\subsection{Estimation Period, Definition and Calculation of Variables}

The equations from 1 to 6 are estimated using data for the period from 1984 to 2016 for China. The data on China's real manufacturing value added are obtained from GGDC 10-Sector Database published by the Groningen Growth and Development Center (Timmer et al. 2014) over the period 1978-2004 and completed by the data published by in China Statistical Yearbooks and United Nation Statistics Division (UNSD), which publishes the data since 2004. The homogeneity of the three databases is checked.

We have calculated three renminbi manufacturing real exchange rates at macro, micro and sector levels. USA is the first trade partner in the calculation of macro real exchange rate. it is the first partner only for 23 products among 188 products in the calculation of product real exchange rate. Manufacturing employment comes from China statistical yearbook 2009 for the period 1984-2002 and 2012-2016 and from GGDC for the period from 2003 to 2011. Manufacturing capital intensity is the ratio of capital stock relative to employment in manufacturing sector. We use the permanent inventory method to calculate the capital stock. The importance of non-SOE enterprises is the ratio of manufacturing employment in non-state owned enterprises to the total manufacturing employment. Real exports of manufactured goods are nominal exports of manufacturing exports deflated its unit value $(2010=100)$, both are taken from UNCTAC statistic. FDI is the stock in manufacturing sector, published in China Statistical Yearbooks. Table A1 gives definitions and sources of variables.

\subsection{Econometric Tests and Estimation Method}

We firstly test the unit roots of studied variables. The results show that they are not stationary at absolute level I (0), but are integrated at first difference I (1). Regressing manufacturing value added on its explanatory variables at absolute level is an appropriate estimation strategy if and only if the residual is stationary I (0) (Eberhardt and Teal, 2011; 2013a, b). The obtained results of Johanson cointegration test show that manufacturing value added and its explanatory variables are cointegrated I $(0)$ and the estimation residuals are stationary I (0). Consequently, the regression of manufacturing value added at absolute level is not spurious and there is a long run relationship between the studied variables. Second, as all variables are stationary at I(1), the growth rate of manufacturing value added can be regressed on growth rates of its explanatory variables to obtain short-run effects. The obtained results of Granger-causality test show Granger-causality from real exchange rate to other variables. Finally, an error correction model (ECM) is applied to capture the long-run equilibrium relationship of all variables and to identify if there is short-run dynamics which tend to long-run equilibrium (Campbell and Shiller, 1988). The obtained results reported in columns 5 and 6 table 2 show that the error correction term coefficient lagged one period is negative and statistically significant, confirming that there exists an adjustment of short-run dynamics to long-run equilibrium between manufacturing value added and its explanatory variables. 
Table 2. Effects of macro real exchange rate on manufacturing value added: 1984-2016

\begin{tabular}{|c|c|c|c|c|c|c|}
\hline & 1 & 2 & 3 & 4 & 5 & 6 \\
\hline & Long-run & Long-run & Short-run & Short-run & ECM & ECM \\
\hline $\operatorname{Ln}($ Macro real effective exchange rate ) & $\begin{array}{c}0.32 * * * \\
(3.69)\end{array}$ & $\begin{array}{c}0.29 * * * \\
(3.98)\end{array}$ & $\begin{array}{l}0.20^{* *} \\
(2.02)\end{array}$ & $\begin{array}{l}0.17 * \\
(1.95)\end{array}$ & $\begin{array}{c}0.31 * * * \\
(3.06)\end{array}$ & $\begin{array}{c}0.24 * * * \\
(3.40)\end{array}$ \\
\hline Ln(Capital intensity in manufacturing ) & $\begin{array}{c}0.51 * * * \\
(6.54)\end{array}$ & $\begin{array}{c}0.41 * * * \\
(5.07)\end{array}$ & $\begin{array}{c}0.46^{* * *} \\
(5.05)\end{array}$ & $\begin{array}{c}0.37 * * * \\
(5.00)\end{array}$ & $\begin{array}{c}0.47 * * * \\
(6.72)\end{array}$ & $\begin{array}{c}0.37 * * * \\
(6.45)\end{array}$ \\
\hline $\operatorname{Ln}($ Employment in manufacturing $)$ & $\begin{array}{c}0.61 * * * \\
(3.05)\end{array}$ & $\begin{array}{c}0.55 * * * \\
(3.09)\end{array}$ & $\begin{array}{l}0.40 * * \\
(2.74)\end{array}$ & $\begin{array}{l}0.36 * * \\
(2.46)\end{array}$ & $\begin{array}{c}0.43 * * * \\
(3.20)\end{array}$ & $\begin{array}{l}0.36^{* *} \\
(2.80)\end{array}$ \\
\hline $\operatorname{Ln}($ Real exports of manufactured goods) & $\begin{array}{l}0.22 * * \\
(2.34)\end{array}$ & & $\begin{array}{l}0.16^{* *} \\
(2.23)\end{array}$ & & $\begin{array}{l}0.15^{* *} \\
(2.30)\end{array}$ & \\
\hline $\operatorname{Ln}($ Real ordinary exports of manufactured goods) & & $\begin{array}{c}0.16 * * * \\
(3.57) \\
\end{array}$ & & $\begin{array}{c}0.17 * * * \\
(3.31)\end{array}$ & & $\begin{array}{l}0.13 * * \\
(2.44)\end{array}$ \\
\hline $\operatorname{Ln}($ Real FDI in manufacturing ) & $\begin{array}{c}0.02 \\
(0.28)\end{array}$ & $\begin{array}{l}0.11^{*} \\
(1.74)\end{array}$ & $\begin{array}{c}0.12 \\
(1.52)\end{array}$ & $\begin{array}{l}0.16^{*} \\
(1.87)\end{array}$ & $\begin{array}{l}0.11^{*} \\
(1.69)\end{array}$ & $\begin{array}{l}0.15^{* *} \\
(2.38)\end{array}$ \\
\hline $\mathrm{Ln}$ (Private share in total manufacturing ) & $\begin{array}{c}0.32 * * * \\
(5.16) \\
\end{array}$ & $\begin{array}{c}0.29 * * * \\
(5.22) \\
\end{array}$ & $\begin{array}{c}0.22 * * * \\
(3.03) \\
\end{array}$ & $\begin{array}{c}0.19 * * * \\
(3.25) \\
\end{array}$ & $\begin{array}{c}0.22 * * * \\
(3.18) \\
\end{array}$ & $\begin{array}{c}0.22 * * * \\
(3.40) \\
\end{array}$ \\
\hline EC coefficient $t_{t-1}$ & & & & & $\begin{array}{c}-0.50^{*} \\
(-1.94)\end{array}$ & $\begin{array}{c}-0.60 * * \\
(-2.09)\end{array}$ \\
\hline Constant & $\begin{array}{c}4.01 \\
(1.22)\end{array}$ & $\begin{array}{c}3.21 \\
(1.07)\end{array}$ & $\begin{array}{l}-0.004 \\
(-0.21)\end{array}$ & $\begin{array}{l}0.005 \\
(0.32)\end{array}$ & $\begin{array}{c}-0.01 \\
(-0.35)\end{array}$ & $\begin{array}{c}0.01 \\
(0.65)\end{array}$ \\
\hline observation numbers & 33 & 33 & 33 & 33 & 33 & 33 \\
\hline ADF unit root test for residual & $\mathrm{I}(0)^{* *}$ & $\mathrm{I}(0)^{* * *}$ & & & & \\
\hline Granger-causality & \multicolumn{6}{|c|}{ From real exchange rate to other variables } \\
\hline Johansen cointegration tests & 1 & 1 & & & & \\
\hline
\end{tabular}

Note: -Variables are at absolute level for long-run regressions (columns 1 and 2), and at first difference level for short-run regressions and error correction estimation (columns $3,4,5,6$ ).

$-*{ }^{* *}$ and $* * *$ indicate significance at the $10 \%, 5 \%$ and $1 \%$ levels of confidence, respectively.

\subsection{Baseline Empirical Results}

The first four columns in Table 2 report the results of the effects of real exchange rates on manufacturing value added in long-run ( $1 \& 2$ columns) and in short-run $(3 \& 4$ columns). When exports are introduced in the regressions 1 and 3 , FDI is not statistically significant; its effect is captured by exports. When only ordinary exports are introduced instead of total exports ${ }^{8}$, FDI is statistically significant. Our comments are based on the regressions 2 and 4 . All control variables are statistically significant. The more China exports manufactured goods, attracts FDI, develops private sector, uses capital intensity form of production and employs the persons in manufacturing sector, the more China products manufactured goods; their estimated coefficients are respectively $0.55,0.11,0.29$, 0.41 and 0.55 in long-run term and $0.36,0.16,0.19,0.37$ and 0.36 in short-run term. The coefficient of real exchange rate is statistically significant and positive ( 0.29 in long-run term in and 0.17 in short-run term); it confirms the hypothesis that the real renminbi appreciation improves manufacturing productivity not only in short-run term but also in long-run term. The results of error correction model reported in $5 \& 6$ columns confirm the positive effect of real appreciation and other control variables on manufacturing value added with a significant adjustment from short-run terms to long-run terms.

8 China's customs distinguish two kinds of exports: ordinary exports by Chinese enterprises and processing exports mainly by foreign-funded societies.
Then to know the total effect of real appreciation on manufacturing value added, the real appreciation is regressed on variables of transmission channels (table 3). As waited, the real appreciation of the renminbi exerts negative effects on exports, FDI, the importance of private sector and employment in manufacturing sector, which themselves influence positively manufacturing. Consequently, the indirect effects of the real exchange rate via ordinary exports of manufactured goods, FDI ratio and the importance of private sector are negative and equal respectively to $-0.06,-0.17,-0.23$ and -0.31 in long-run term and $-0.01,-0.07,-0.02$ and -0.08 in short-run term. Inversely, the real exchange rate exerts a positive long run effect on capital intensity, which itself influence positively on manufacturing; this leads to a positive impact of the real exchange rate $(0.13)$.

Calculation of the total effect of the real exchange rate on productivity growth is given in Table 1 . The negative effects (-0.77 in long-run term and -0.17 in short-run term) are superior to the positive long-run effects ( 0.42 and 0.17$)$, leading a total negative effect of real appreciation on manufacturing value added $(-0.35$ and -0.01$)$.

Not only the coefficients of the real exchange rate are significant, but the elasticity values also show that the results are economically relevant. For instance, during the period of from 2005 to 2016 , the renminbi appreciated at an annual average rate of $4.28 \%$, which has led a decrease of the manufacturing growth rate of $1.5 \%$ per year on average. 
Table 3. Estimation of the channelling variables of the real exchange rate to manufacturing value added: 1984-2016

\begin{tabular}{|c|c|c|c|c|c|c|}
\hline & 7 & 8 & 9 & 10 & 11 & 12 \\
\hline Long-run regressions & $\begin{array}{c}\text { Export of } \\
\text { manufactured } \\
\text { goods }\end{array}$ & $\begin{array}{l}\text { Ordinary export } \\
\text { of manufactured } \\
\text { goods }\end{array}$ & $\begin{array}{l}\text { Manufacturing } \\
\text { FDI }\end{array}$ & $\begin{array}{l}\text { Private share in } \\
\text { manufacturing }\end{array}$ & $\begin{array}{l}\text { Manufacturing } \\
\text { Capital intensity }\end{array}$ & $\begin{array}{c}\text { Manufacturing } \\
\text { employment }\end{array}$ \\
\hline Real effective exchange rate & $\begin{array}{c}-0.54 * * * \\
(-4.04) \\
\end{array}$ & $\begin{array}{c}-0.35^{* * *} \\
(-3.42) \\
\end{array}$ & $\begin{array}{c}-1.58 * * * \\
(-5.97) \\
\end{array}$ & $\begin{array}{c}-0.81 * * * \\
(-3.67) \\
\end{array}$ & $\begin{array}{c}0.31^{* * * *} \\
(3.00)\end{array}$ & $\begin{array}{c}-0.56 * * * \\
(-6.08)\end{array}$ \\
\hline Trend & $\begin{array}{c}0.17 * * * \\
(61.3)\end{array}$ & $\begin{array}{c}0.16^{* * * *} \\
(53.5)\end{array}$ & $\begin{array}{c}0.17 * * * \\
(30.5)\end{array}$ & $\begin{array}{c}0.11^{* * *} \\
(14.3)\end{array}$ & $\begin{array}{c}0.10^{* * * *} \\
(43.1)\end{array}$ & $\begin{array}{c}0.01 * * * \\
(3.58)\end{array}$ \\
\hline Constant & $\begin{array}{l}25 * * * \\
(41.7)\end{array}$ & $\begin{array}{c}24.3^{* * *} \\
(47.5)\end{array}$ & $\begin{array}{c}28.2^{* * *} \\
(22.6)\end{array}$ & $\begin{array}{c}3.40^{* * *} \\
(2.85)\end{array}$ & $\begin{array}{c}7.46^{* * *} \\
(14.8)\end{array}$ & $\begin{array}{c}20.9^{* * *} \\
(52.9)\end{array}$ \\
\hline Short-run regressions & 13 & 14 & 15 & 16 & 17 & 18 \\
\hline Real effective exchange rate & $\begin{array}{c}-0.55 * * * \\
(-3.09) \\
\end{array}$ & $\begin{array}{c}-0.05 * * * \\
(-3.23) \\
\end{array}$ & $\begin{array}{l}-0.44 * \\
(-1.74) \\
\end{array}$ & $\begin{array}{c}-0.10 \\
(-0.42) \\
\end{array}$ & $\begin{array}{l}0.005 \\
(0.04) \\
\end{array}$ & $\begin{array}{l}-0.21 * \\
(-1.93) \\
\end{array}$ \\
\hline Constant & $\begin{array}{c}0.15^{* * *} \\
(8.53)\end{array}$ & $\begin{array}{c}0.12 * * * \\
(5.33)\end{array}$ & $\begin{array}{c}0.18^{* * *} \\
(7.04)\end{array}$ & $\begin{array}{c}0.11 * * * \\
(4.55)\end{array}$ & $\begin{array}{c}0.11^{* * *} \\
(9.35)\end{array}$ & $\begin{array}{c}0.01 \\
(0.96)\end{array}$ \\
\hline Number of observations & 33 & 33 & 33 & 33 & 33 & 33 \\
\hline
\end{tabular}

Notes: ${ }^{* *}$ and $* * *$ indicate significance at the $10 \%, 5 \%$ and $1 \%$ levels of confidence, respectively.

\subsection{Robustness Tests}

The impact of real exchange rate can be different according to products and sectors (Dhasmana, 2015). As robustness tests, we repeated the same estimations using the two micro real exchange rates, which have advantage to reduce potential endogeneity issues. The obtained results confirmed again that the real appreciation of the renminbi micro product real exchange rate exerts a positive effect on manufacturing value added beside its negative effects on the variables of tradable sector and employment and its positive effect on capital intensity (table 4). The error correction terms are significant, confirming again there is a short-term adjustment towards long-term equilibrium. The coefficients of micro product real exchange rate are higher than those of macro one suggest that micro product real exchange rate captures better the impact of real exchange rate on manufacturing value added.

Table 4. Effects of micro product real exchange rate on manufacturing value added: 1994-2016

\begin{tabular}{|c|c|c|c|c|c|c|}
\hline & $1 \mathrm{~b}$ & $2 \mathrm{~b}$ & $3 b$ & $4 \mathrm{~b}$ & $5 b$ & $6 \mathrm{~b}$ \\
\hline & Long-run & Long-run & Short-run & Short-run & ECM & ECM \\
\hline $\mathrm{Ln}$ (product real exchange rate ) & $\begin{array}{c}0.60 * * * \\
(4.33)\end{array}$ & $\begin{array}{c}0.48 * * \\
(2.11)\end{array}$ & $\begin{array}{l}0.42 * \\
(1.77)\end{array}$ & $\begin{array}{l}0.35^{*} \\
(1.95)\end{array}$ & $\begin{array}{c}0.57 * * * \\
(3.59)\end{array}$ & $\begin{array}{c}0.52 * * * \\
(3.03)\end{array}$ \\
\hline $\operatorname{Ln}($ Capital intensity in manufacturing $)$ & $\begin{array}{c}0.35 * * * \\
(4.23)\end{array}$ & $\begin{array}{c}0.38^{* * * *} \\
(3.46)\end{array}$ & $\begin{array}{c}0.36 \\
(1.36)\end{array}$ & $\begin{array}{c}0.31 \\
(1.11)\end{array}$ & $\begin{array}{l}0.44 * * \\
(2.49)\end{array}$ & $\begin{array}{l}0.47 * * \\
(2.43)\end{array}$ \\
\hline Ln(Employment in manufacturing ) & $\begin{array}{c}0.60 * * * \\
(4.33)\end{array}$ & $\begin{array}{c}0.65^{* * * *} \\
(3.97)\end{array}$ & $\begin{array}{l}0.49^{*} \\
(1.82)\end{array}$ & $\begin{array}{l}0.46^{*} \\
(1.79)\end{array}$ & $\begin{array}{c}0.59 * * * \\
(3.33)\end{array}$ & $\begin{array}{l}0.28 * * \\
(3.35)\end{array}$ \\
\hline $\operatorname{Ln}($ Real exports of manufactured goods) & $\begin{array}{l}0.34 * * \\
(4.52)\end{array}$ & & $\begin{array}{l}0.25^{* *} \\
(2.52)\end{array}$ & & $\begin{array}{l}0.30^{* *} \\
(4.61)\end{array}$ & \\
\hline $\operatorname{Ln}($ Real ordinary exports of manufactured goods) & & $\begin{array}{c}0.25^{* * *} \\
(3.18) \\
\end{array}$ & & $\begin{array}{l}0.17^{*} \\
(1.95)\end{array}$ & & $\begin{array}{l}0.21 * * \\
(3.58)\end{array}$ \\
\hline $\operatorname{Ln}($ Real FDI in manufacturing ) & $\begin{array}{c}-0.02 \\
(-0.42)\end{array}$ & $\begin{array}{c}0.02 \\
(0.35)\end{array}$ & $\begin{array}{l}-0.02 \\
(0.18)\end{array}$ & $\begin{array}{c}0.02 \\
(0.22)\end{array}$ & $\begin{array}{c}-0.04 \\
(-0.66)\end{array}$ & $\begin{array}{c}-0.04 \\
(-0.53)\end{array}$ \\
\hline $\operatorname{Ln}($ Private share in total manufacturing ) & $\begin{array}{l}0.14 * * \\
(2.31)\end{array}$ & $\begin{array}{c}0.25^{* * *} \\
(4.30))\end{array}$ & $\begin{array}{l}0.18^{*} \\
(1.63)\end{array}$ & $\begin{array}{c}0.21 \\
(1.72)\end{array}$ & $\begin{array}{l}0.18^{* *} \\
(2.52)\end{array}$ & $\begin{array}{c}0.28 * * * \\
(3.35)\end{array}$ \\
\hline EC coefficient $t_{t-1}$ & & & & & $\begin{array}{c}-1.12 * * * \\
(-4.29)\end{array}$ & $\begin{array}{r}-1.02 * * \\
(-4.11)\end{array}$ \\
\hline Constant & $\begin{array}{c}0.47 \\
(0.17)\end{array}$ & $\begin{array}{c}0.71 \\
(0.21)\end{array}$ & $\begin{array}{c}0.11 \\
(0.31)\end{array}$ & $\begin{array}{c}0.02 \\
(0.59)\end{array}$ & $\begin{array}{c}-0.01 \\
(-0.35)\end{array}$ & $\begin{array}{c}0.01 \\
(0.65)\end{array}$ \\
\hline Number of observations & 21 & 21 & 31 & 31 & 31 & 31 \\
\hline ADF unit root test for residual & $\mathrm{I}(0)^{* *}$ & $\mathrm{I}(0)^{* * *}$ & & & & \\
\hline Johansen cointegration tests & 1 & 1 & & & & \\
\hline
\end{tabular}

Note: -Variables are at absolute level for long-run regressions (columns 1 and 2), and at first difference level for short-run regressions and error correction estimation (columns $3,4,5,6$ ).

$-*, * *$ and $* * *$ indicate significance at the $10 \%, 5 \%$ and $1 \%$ levels of confidence, respectively.

Finally, the recent publication of WIOD on value added, employment and capital stocks at industrial sectors allows us to estimate panel data on 18 manufacturing sectors over the 2006 to 2014 period, which were marked by strong real appreciation of the renminbi. We introduced only export variables because sectorial FDI and private share in manufacturing are unavailable. All variables are legged one period to avoid potential endogeneity issue. The obtained results confirmed the positive effect of the renminbi appreciation of sector real exchange rate on manufacturing productivity improvement besides its negative effect via its impact on exports of manufactured goods (Table 5). 
Table 5. Impact of renminbi real appreciation on manufacturing value added for 18 industrial sectors over 2006-2014 period

\begin{tabular}{|l|c|c|c|c|c|}
\hline & MVA & MVA & $\begin{array}{c}\ln (\text { Exports of } \\
\text { manufactured goods) }\end{array}$ & In(capital intensity) & $\begin{array}{c}\text { Ln(manufacturing } \\
\text { employment) }\end{array}$ \\
\hline Ln(sector real exchange rate) -1 & & $\begin{array}{c}2.14^{*} \\
(1.87)\end{array}$ & $\begin{array}{c}-1.76^{* * *} \\
(-3.27)\end{array}$ & $\begin{array}{c}0.61^{* *} \\
(2.01)\end{array}$ & $\begin{array}{c}-0.68^{* *} \\
(-1.93)\end{array}$ \\
\hline Ln(Exports of manufactured & $\begin{array}{c}0.21^{*} \\
(1.86)\end{array}$ & $\begin{array}{c}0.21^{*} \\
(1.93)\end{array}$ & & & \\
goods)-1 & $\begin{array}{c}1.64^{* * *} \\
(7.93)\end{array}$ & $\begin{array}{c}1.49^{* * *} \\
(6.82)\end{array}$ & & & \\
\hline Ln(Capital intensity)-1 & $\begin{array}{c}2.14^{* * *} \\
(12.8)\end{array}$ & $\begin{array}{c}2.05^{* * *} \\
(11.8)\end{array}$ & & & \\
\hline Ln(manufacturing & 144 & 144 & 144 & 144 & 144 \\
\hline employment)-1 & 18 & 18 & 18 & 18 & 18 \\
\hline Number of observations & & & & \\
\hline
\end{tabular}

Note: $*, * *$ and $* * *$ indicate significance at the $10 \%, 5 \%$ and $1 \%$ levels of confidence, respectively.

\section{Summary and Concluding Remarks}

In this paper, we theoretically underpinned and empirically estimated the different (positive and negative) impacts of real appreciation of exchange rate on manufacturing value added in the case of China. If negative effects of real appreciations on manufacturing value added are quite traditional, few studies estimated its positive effects. We argued that, besides its traditional negative effects through its impact on the size of tradable sector and employment, real appreciation exerts positive effects on capital intensity and improves manufacturing productivity via efficiency of workers and staffs, Schumpeterian "creative destruction," innovation and high technology industries. We proposed a real exchange rate augmented function of manufacturing value added able to distinguish the positive effects from the negative ones, and then applied to China. We calculated three manufacturing real effective exchange rates of the renminbi at macro, product and sector levels. The obtained results confirm the positive impacts of real appreciation through capital intensity and productivity improvement, and its negative effects via transmission channels variables such exports, FDI, private importance in manufacturing sector and employment both in short-run and long-run terms with an adjustment towards equilibrium. They show that the positive effects are not enough to set off the negative effects, leading finally a total negative effect. The real appreciation of the renminbi of $43 \%$ pa during the period 2005-2016 has led a decrease of $15 \%$ of manufacturing value added, but it has helped the Chinese manufacturing productivity as shown in Fig. 3.

These results suggest that if manufacturing development depends relative price competition (via devaluations) which is particularly important at the beginning of industrialization, it also depends productivity improvement during industrialization process to mitigate the traditional negative effects. The contrasted growth rates of China's manufacturing value added since 1994 relative to the precedent period show that manufacturing upgrading via appreciation-led productivity improvement is much more difficile than depreciation-led labor-intensive industry growth, but it is essential to avoid middle-income traps and to become industrialized country. These results suggest that China should gradually revalue the renminbi in function of manufacturing productivity improvement to avoid the serious deceleration of manufacturing industry when its negative impacts on the size of tradable sector, resource allocation to non-tradable sector and employment are superior to positive effects of productivity improvement. This allows China to upgrade its manufacturing industry from low cost labour intensive industry to capital intensive one based on innovation and technologies and to move from low value chains up to high ones.

\section{Acknowledgements}

This work was supported by the Agence Nationale de la Recherche of the French government through the program 'Investissements d'avenir' 'ANR-10-LABX-14-01' and by La Fondation pour les Etudes et Recherches sur le Développement International (Ferdi). We thank Martine BOUCHUT (CERDI) for her assistance for the calculation of the original data of real exchange rates. We thank professor Yun-Wing Sung, the discussant and other participants of the Conference on China's Reform and Opening Up: Economic Development and Structural Change, October 13-14, 2018, Zhejiang University, Hangzhou, China, and of the Conference on China's Economic Reforms: Where Do We Stand, December 3-4, 2018, Global Research Unit, Department of Economics \& Finance, City University of Hong Kong, Bank of Finland Institute for Economies in Transition (BOFIT) and Gabelli School of Business, Fordham University for suggestions and comments. The remaining errors are mine. 


\section{Annex 1: Definitions and Sources of Variables}

\begin{tabular}{|c|c|c|}
\hline Names of variables & Calculation method & Source \\
\hline $\begin{array}{l}\text { Real manufacturing } \\
\text { value added }\end{array}$ & Real manufacturing value added expressed in 2010 yuans & $\begin{array}{l}\text { GGDC 10-Sector Database, } \\
\text { Groningen Growth and } \\
\text { Development Centre (GGDC) and } \\
\text { United Nation Statistics Division } \\
\text { (UNSD). }\end{array}$ \\
\hline $\begin{array}{l}\text { Macro manufacturing } \\
\text { real effective } \\
\text { exchange rate }\end{array}$ & $\begin{array}{l}\text { Ratio of China's consumer price index }(2010=100) \text { to the average consumer } \\
\text { price index of its main export partners of manufactured goods, all prices being } \\
\text { converted into the same currency. }\end{array}$ & $\begin{array}{l}\text { IMF, International Financial } \\
\text { Statistics }\end{array}$ \\
\hline $\begin{array}{l}\text { Manufacturing } \\
\text { product real effective } \\
\text { exchange rate }\end{array}$ & $\begin{array}{l}\text { A weighted product of } 188 \text { products real effective exchange rates in function } \\
\text { of their importance in the total exports of } 188 \text { products at HS } 4 \text { level. Product } \\
\text { real effective exchange rate is calculated as the product of consumer price of } \\
\text { China and the weighted consumer price of the ten most important world } \\
\text { exporters expressed in the same currency. }\end{array}$ & $\begin{array}{l}\text { IMF, International Financial } \\
\text { Statistics } \\
\text { UN Comtrade }\end{array}$ \\
\hline $\begin{array}{l}\text { Manufacturing sector } \\
\text { real effective } \\
\text { exchange rate }\end{array}$ & $\begin{array}{l}\text { The micro manufacturing sector real effective exchange rates of the renminbi } \\
\text { is calculated for } 18 \text { manufacturing sectors according to ISIC revision } 4 \text {. }\end{array}$ & $\begin{array}{l}\text { IMF, International Financial } \\
\text { Statistics } \\
\text { WIOD }\end{array}$ \\
\hline $\begin{array}{l}\text { Capital intensity in } \\
\text { manufacturing sector }\end{array}$ & $\begin{array}{l}\text { Capital stock divided by employed population. The inventory permanent } \\
\text { method is used to calculate the capital stock deflated by the "price index of } \\
\text { gross fixed capital formation," and the "price index of investment in fixed } \\
\text { assets" available since } 1990 \text {. The first series is used for the period from } 1972 \\
\text { to } 1990 \text { and the second for the following years. }\end{array}$ & 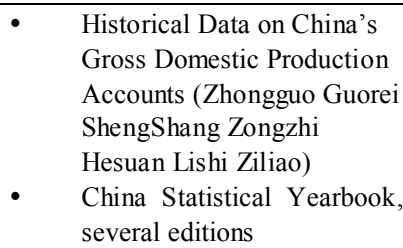 \\
\hline $\begin{array}{c}\text { Real exports of } \\
\text { manufactured goods }\end{array}$ & Exports of manufactured goods divided by export unit value & $\begin{array}{l}\text { China Statistical Yearbook, } \\
\text { UNCTAD statistics }\end{array}$ \\
\hline Real ordinary exports & Ordinary Exports of manufacturing goods divided by export unit value & $\begin{array}{l}\text { China Statistical Yearbook, } \\
\text { UNCTAD statistics }\end{array}$ \\
\hline Real FDI & Foreign direct investments divided by gross formation of fixed capital & China Statistical Yearbooks \\
\hline Private importance & Private share in total manufacturing employment & $\begin{array}{l}\text { GGDC, China Statistical } \\
\text { Yearbooks }\end{array}$ \\
\hline
\end{tabular}

\section{REFERENCES}

[1] Alfaro, L, A Cuñat, H Fadinger and Y Liu. 2018. "The real exchange rate, innovation and productivity: Regional heterogeneity, asymmetries and hysteresis," NBER, Working Paper 24633.

[2] Benaroya F. and D Janci. 1999. "Measuring exchange rates misalignments with purchasing power parity estimates", 165-187, in Exchange rate policies in emerging Asian countries, edited by Stefan Collignon, Jean Pisani-Ferry and Yung Chul Park Routledge, New York

[3] Berg A. and Y. L. Miao. 2010. "The Real Exchange Rate and Growth Revisited: The Washington Consensus Strikes Back?" IMF working paper WP/10/58.

[4] Boeing P., E. Mueller and P. Sandner (2015) China's R\&D Explosion - Analyzing Productivity Effects Across Ownership Types and Over Time, Discussion Paper No. 15-006, ZEW, Centre for European Economic Research.

[5] Brandt L., J. V. Biesebroeck and Y. Zhang. 2012. "Creative accounting or creative destruction? Firm-level productivity growth in Chinese manufacturing," Journal of Development Economics, 97, 339-351.

[6] Campbell J. Y. and R. J. Shiller. 1988. "Interpreting
Cointegrated Models," Journal of Economic Dynamics and Control, 12, 505-522.

[7] Chen R. and D. Mai. 2011. "The Real Exchange Rate and Employment in China," IMF Working Paper 11/148.

[8] Chen, Y., I. Mitsuru and S. Masayuki and X. Mo, Privatization and Productivity in China (2019). Available at SSRN: https://ssrn.com/abstract=2695933 orhttp://dx.doi.org/10.2139/ssrn.2695933, October.

[9] Dai X. Y., Z. Sun and H. Liu. 2019. "Decomposing the contribution of firm innovation to aggregate productivity growth: the case of Chinese manufacturing industry," Applied Economics Letters, 26 (7), 543-548.

[10] Dougherty, S. H. Richard and P. He. 2007. "Has a private sector emerged in China's industry? Evidence from a quarter of a million Chinese firms". China Economic Review 18 (3): 309-334.

[11] Dhasmana A. 2015. Transmission of real exchange rate changes to the manufacturing sector: The role of financial Access, International Economics, 143, 48-69.

[12] Dollar, David. 1992. "Outward-oriented developing economies really do grow more rapidly: Evidence from 95 LDCs, 1976-1985. Economic Development and Cultural Change 40(3): 523-544.

[13] Eberhardt, M. and F. Teal. 2011. Econometrics for grumblers: A new look at the literature on cross-country growth empirics. Journal of Economic Surveys, 
25(1):109-155.

[14] Eberhardt, M. and F. Teal 2013a. No mangoes in the tundra: Spatial heterogeneity in agricultural productivity analysis. Oxford Bulletin of Economics and Statistics, 75(6):914-939.

[15] Eberhardt, M. and F. Teal, 2013b. Structural change and cross-country growth empirics. Policy Research Working Paper Series 6335, The World Bank.

[16] Eichengreen, B. 2008. The Real Exchange Rate and Economic Growth. Commission on Growth and Development Working Paper, No. 4, the World Bank.

[17] Fu, X. and V. N. Balasubramanyam. 2005. "Exports, Foreign Direct Investment and Employment: The Case of China". The World Economy 28(4): 607-625.

[18] Jefferson, G. H. and J. Su. 2006. "Privatization and restructuring in China: Evidence from shareholding ownership, 1995-2001". Journal of Comparative Economics 34(1): 146-166.

[19] Gebre-Egziabher, T. 2009. "The development impact of Asian drivers on Ethiopia with emphasis on small-scale footwear producers, The World Economy, 32(11), $1613-1637$

[20] Guillaumont-Jeanneney S. and P. Hua. 2011. "How does Real Exchange Rate influence labour productivity in China?" China Economic Review 22(4): 628-645.

[21] Guzman M., J. A. Ocampo and J. E. Stiglitz. 2018. Real exchange rate policies for economic development, World Development 110, 51-62.

[22] Harris, R. G. 2001. "Is There a Case for Exchange Rate Induced Productivity Declines?" 277-309, in Re-Visiting the Case for Flexible Exchange Rates, edited by Lawrence Schembri, Bank of Canada, Ottawa.

[23] Hausmann R.; L. Pritchett and D. Rodrik. 2005. Growth Accelerations. Journal of Economic Growth 10 (4), 303-329.

[24] Hua, P. 2007. "Real exchange rate and manufacturing employment in China”. China Economic Review 18 (3): 335-353.

[25] Hua P. 2012. "Real exchange rate and economic growth in China," Journal of Reviews on Global Economics, $\mathrm{n}^{\circ} 1$, 2012, pp. 89-105.

[26] Huang J. B., X. C. Cai, S. Tian, H. Y. Lei. 2019. Technological factors and total factor productivity in China: Evidence based on a panel threshold model, China Economic Review, 54, April, 271-285.

[27] Jefferson G. H., H. Bai, X. Guan and X. Yu (2006) "R\&D Performance in Chinese industry," Economics of innovation and New Technology, 15 (4-5).
[28] Kraay, A. 2006. "Exports and economic performance: Evidence from a panel of Chinese enterprises". 139 - 160, in Global Integration and Technology Transfer, edited by Hoekman, Beata and Smarzynska Javorcik, Washington DC: The World Bank.

[29] Krugman P. 1989. "Surévaluation et accélération des productivités: un modèle spéculatif". 121-135, in Commerce international et concurrence parfaite, edited by Didier Laussei et Christian Montet, Paris, Economica.

[30] Leng S. (2018) "China's once-booming textile and clothing industry faces tough times," South China Morning post, 30 April 2018.

[31] Li, Xiaoying; Xiaming Liu and David Parker. 2001. "Foreign Direct Investment and productivity Spillovers in the Chinese Manufacturing sector". Economic System 25(4): 305-321.

[32] Lovely M. E. and Z. Huang 2018. "Foreign Direct Investment in China's High-technology Manufacturing Industries," China \& World Economy, 104-126, 26 (5).

[33] MacDonald, R. R. and F. V. Vieira. 2010. A Panel Data Investigation of Real Exchange Rate Misalignment and Growth, May 1. CESifo Working Paper Series 3061.

[34] Razmi, A., M. Rapetti \& P. Skott (2012). The real exchange rate and economic development. Structural Change and Economic Dynamics, 23(2), 151-169.

[35] Redi, O. (2009) "From ashes, an industry reborn, Fortune (Addis Ababa) March 22.

[36] Rodrik, D. (2008). "The Real Exchange Rate and Economic Growth," Brookings Papers on Economic Activity 2, 365412 .

[37] Rodrik, D. (2016). "Premature deindustrialization," Journal of Economic Growth, 21:1-33

[38] Salvacion M. (2006) More Foreign Firms Expected to Close, Move Out of Dongguan Oct 26, 2015 07:40 AM EDT.

[39] Schumpeter, J. (1942). Capitalism, Socialism, and Democracy. New York: Harper \& Bros.

[40] Sonobe T., J. E. Akoten and K. Otsuka 2009. An exploration into the successful development of the leather-shoe industry in Ethiopia, Review of Development Economics, 13(4) 719-734.

[41] Timmer M.P., G.J. de Vries and K. de Vries 2014 "Patterns of structural change in developing countries." GGDC research memorandum, 149.

[42] UNIDO 2010. Industrial Statistics: Guidelines and Methodology, Vienna, Austria.

[43] Zhou Yi, C.F. He and S.J. Zhu, 2017. "Does Creative Destruction Work for Chinese Regions? Growth and change, 48 (3), September 274-296. 